\title{
Analysis of the complement sensitivity of oral treponemes and the potential influence of FH binding, FH cleavage and dentilisin activity on the pathogenesis of periodontal disease
}

\author{
D.P. Miller ${ }^{1}$, J.V. McDowell ${ }^{1}$, J.K. Bell ${ }^{2}$, M.P. Goetting-Minesky ${ }^{3}$, J.C. Fenno ${ }^{3}$ and R.T. Marconi ${ }^{1,4}$ \\ 1 Department of Microbiology and Immunology, Medical College of Virginia, Virginia Commonwealth University, Richmond, VA, USA \\ 2 Department of Biochemistry and Molecular Biology, Medical College of Virginia, Virginia Commonwealth University, Richmond, VA, USA \\ 3 Department of Biologic and Materials Sciences, School of Dentistry, University of Michigan, Ann Arbor, MI, USA \\ 4 Center for the Study of Biological Complexity, Medical College of Virginia, Virginia Commonwealth University, Richmond, VA, USA
}

Correspondence: Richard T. Marconi, Department of Microbiology and Immunology, P.O. Box 980678, Virginia Commonwealth University, Richmond, VA 23298, USA Tel.: +1 804828 3779; fax: +1 804827 1310; E-mail: rmarconi@vcu.edu

Keywords: complement; dentilisin; FhbB; periodontitis; Treponema denticola

Accepted 4 May 2014

DOI: $10.1111 /$ omi.12054

\section{SUMMARY}

Treponema denticola, a periopathogen, evades complement-mediated killing by binding the negative complement regulatory protein factor $\mathrm{H}(\mathrm{FH})$ to its surface via the FhbB protein. Paradoxically, bound FH is cleaved by $T$. denticola's dentilisin protease, a process hypothesized to trigger localized dysregulation of complement activation in periodontal pockets. The ability of other oral treponemes to evade complement-mediated killing and bind and cleave FH has not been assessed. In this report, we demonstrate that representative isolates of Treponema socranskii, Treponema medium, Treponema pectinovorum and Treponema maltophilum are also serum resistant, whereas Treponema vincentii and Treponema amylovorum are serum sensitive. Although T. denticola's ability to evade complement-mediated killing is strictly dependent on FH binding, other serum-resistant treponemal species lack $\mathrm{FhbB}$ and do not bind $\mathrm{FH}$, indicating an FH-independent mechanism of complement evasion. To assess the influence of $\mathrm{FhbB}$ sequence variation on FH binding and cleavage by $T$. denticola, fhbB sequences were determined for 30 isolates. Three distinct phyletic types were identified. All $T$. denticola strains bound $\mathrm{FH}$ and were serum resistant, but differences in binding kinetics, dentilisin activity and FH cleavage ability were observed. Based on these analyses, we hypothesize that the composition of the $T$. denticola population is a determining factor that influences the progression and severity of periodontal disease.

\section{INTRODUCTION}

Periodontitis is a chronic inflammatory disease initiated by a complex microbial biofilm that results in destruction of the periodontium, culminating in alveolar bone resorption and edentulism (Darveau, 2010). Distinct bacterial consortia have been identified that correlate with either healthy or diseased tissue. Elevated numbers of bacteria in the 'red-complex' (Porphyromonas gingivalis, Tannerella forsythia and Treponema denticola) correlate strongly with periodontal disease progression and severity (Socransky et al., 1998). Oral treponemes, including T. denticola, are anaerobic spirochetes that are found at the 
interface between the subgingival plaque and the periodontal epithelium (Ellen \& Galimanas, 2005). Treponema denticola is a minor component of the bacterial population in the healthy subgingiva but may exceed $40 \%$ of the total bacterial population in diseased periodontal pockets (Ellen \& Galimanas, 2005).

The subgingival crevice is bathed in crevicular fluid that is rich in serum proteins, antimicrobial peptides and active complement (Schenkein \& Genco, 1977b; Boackle et al., 1978; Boackle, 1991). Complement is a key part of the innate immune system (Ricklin et al., 2010). Host cells are protected from activated complement by membrane-bound and fluid-phase complement regulators including factor $\mathrm{H}(\mathrm{FH})$. $\mathrm{FH}$ is a $155-k D a$ glycoprotein that consists of 20 complement control protein (CCP) domains and binds to host cell glycosaminoglycans via CCPs 6-7 and 19-20 (Ferreira et al., 2010). Although $\mathrm{FH}$ is a key regulator of the alternative complement pathway, its ability to influence several immunological pathways and processes that are relevant to periodontal disease is now clear (Mihlan et al., 2009; Zipfel \& Skerka, 2009; Ferreira et al., 2010; Barthel et al., 2012).

Treponema denticola strain 35405 exploits the negative complement regulatory activity of $\mathrm{FH}$ by binding it to an 11.4-kDa surface exposed lipoprotein designated as FhbB (McDowell et al., 2005, 2007). The binding interaction occurs between the negatively charged face of FhbB and the CCP 7 domain of $\mathrm{FH}$ (McDowell et al., 2005, 2007; Miller et al., 2011, 2012). Using a T. denticola $35405 \mathrm{fhbB}$ deletion mutant $(35405 \delta \mathrm{fhbB})$, it was demonstrated that serum resistance is strictly dependent on this interaction (McDowell et al., 2011). Paradoxically, FH bound to the $T$. denticola surface is cleaved by the protease dentilisin (McDowell et al., 2009). It has been hypothesized that as the $T$. denticola population expands with disease progression, cleavage of $\mathrm{FH}$ by dentilisin leads to local dysregulation of complement activation initiating a cascade of destructive downstream events that result in tissue destruction and bone resorption (Miller et al., 2012). This in turn creates a favorable environment for the survival of other periopathogens.

In this study, we assessed the complement sensitivity of six oral treponeme species in addition to a comprehensive panel of $T$. denticola strains. All $T$. denticola strains were determined to be serum resistant and to bind $\mathrm{FH}$. However, other species that were serum resistant did not produce FhbB or bind $\mathrm{FH}$, indicating that they employ alternative methods for complement evasion. Since FhbB and FH binding has, to date, been assessed in only four $T$. denticola strains (35405, 33520, 33521 and GM1), in this study we determined $f h b B$ sequences and assessed $\mathrm{FH}$ binding, dentilisin activity and $\mathrm{FH}$ cleavage for a large panel of $T$. denticola isolates (McDowell et al., 2005, 2007). The influence of $f h b B$ sequence variation on $\mathrm{FH}$ binding and serum resistance was also assessed and the kinetics of the FhbB-FH interaction was determined for representative recombinant FhbB proteins using surface plasmon resonance. This study provides a comprehensive analysis of the serum resistance of oral treponemes. The results demonstrate that some oral treponemes employ an $\mathrm{FH}$-independent mechanism to evade complementmediated destruction. In addition, the data indicate significant phenotypic variation among $T$. denticola isolates. This observation is of epidemiological and pathogenic relevance because it suggests that the composition of the $T$. denticola population may influence the progression and severity of disease.

\section{METHODS}

\section{Bacterial strains and generation of recombinant proteins}

Treponema medium (ATCC 700293), Treponema socranskii (ATCC 35535), Treponema vincentii (ATCC 35580) and all strains of $T$. denticola were grown in new oral spirochete media under anaerobic conditions as previously described (McDowell et al., 2005). Treponema amylovorum (ATCC 700288), Treponema maltophilum (ATCC 51939) and Treponema pectinovorum (ATCC 33768) were grown in OMIZ-P4 under anaerobic conditions. Recombinant ( $r-$ FhbB proteins were generated, as previously described, using primers designed to amplify the mature protein (removing the 23 amino acid signal peptide) with sequences that allow for ligase-independent cloning with the pET46 Ek/LIC vector (Table 1) (Miller et al., 2012). Recombinant FH proteins consisting of different CCP domains and r-FhbA, an FHbinding protein from Borrelia hermsii, were generated in earlier studies (Hovis et al., 2008; Miller et al., 2013). 
Table 1 Oligonucleotide primers $\left(5^{\prime}-3^{\prime}\right)$ used in this study ${ }^{1}$

\begin{tabular}{|c|c|}
\hline TDE0107Up & TTTATTCCACCATTCCATACATC \\
\hline TDE0109Rev & CGATATTCATGACGTTTACTAC \\
\hline FhbB1 LIC (+) & GACGACGACAAGATTACTTTCAAAATGAATACTGCAC \\
\hline FhbB1 LIC (-) & GAGGAGAAGCCCGGTTTACTTTATCTTTTTGGGTAT \\
\hline FhbB2 LIC (-) & GAGGAGAAGCCCGGTTTACTTTATCTTCTTGGGTACAAAGCG \\
\hline FhbB3 LIC (+) & GACGACGACAAGATTGCTTTTAAAATGAATACTGCAC \\
\hline FhbB3 LIC (-) & GAGGAGAAGCCCGGTTTACTTTTTCTTGGGTACAAAG \\
\hline CCP1 LIC (+) & GACGACGACAAGAAGGAAGATTGCAATGAACTTCCTCC \\
\hline CCP4 LIC (-) & GAGGAGAAGCCCGGTTCATGATTTTTCTTCACATGAAGGCCAC \\
\hline CCP5 LIC (+) & GACGACGACAAGAAATCATGTGATAATCCTTATATTC \\
\hline CCP6 LIC $(+)$ & GACGACGACAAGAAACCTTGTGATTATCC \\
\hline CCP7 LIC (-) & GAGGAGAAGCCCGGTTCAGACACGGATGCATCTGGGAGTAG \\
\hline CCP8 LIC $(+)$ & GACGACGACAAGAAAAAAACATGTTCCAAATCAAGTATAG \\
\hline CCP13 LIC (-) & GAGGAGAAGCCCGGTTCATGCCATTGAGCAGTTCACTTC \\
\hline CCP14 LIC (+) & GACGACGACAAGAAACAATTATGCCCACCTCCACCTC \\
\hline CCP18 LIC (-) & GAGGAGAAGCCCGGTTCAAGAATCTTTGCATTGAGGTGGTTC \\
\hline CCP19 LIC (+) & GACGACGACAAGATCAAAGATTCTACAGGAAAATGTG \\
\hline CCP20LIC (-) & GAGGAGAAGCCCGGTCTATCTTTTTGCACAAGTTGGATAC \\
\hline
\end{tabular}

${ }^{1}$ The segment of each primer that was included to allow for annealing with the pET46 Ek/LIC vector is indicated by underlining.

\section{DNA sequencing, phylogenetic and structural analyses}

The $f h b B$ gene was amplified using polymerase chain reaction and sequenced from $30 \mathrm{~T}$. denticola strains as previously described (McDowell et al., 2007). The primers used for the polymerase chain reaction are listed in Table 1. Additional sequences, generated as part of the Human Microbiome U54 initiative (broadinstitute.org) derived from $T$. denticola isolates AL-2, F0402, H-22, H-1, MYR, US-Trep1, SP23, SP32, SP33, SP37 and SP34 were also analysed. FhbB sequences were aligned using CLUSTALOMEGA (Sievers et al., 2011) and phylogenetic analyses conducted using MEGA5 (Tamura et al., 2011). Phylogenetic trees were constructed using the neighbor-joining method and the standard errors of distances were computed by bootstrap analysis using 500 replications. The sequences determined as part of this study were assigned GenBank accession numbers HM991217HM991226. The structural relationships among FhbB variants were assessed using computer-assisted structural modeling. A structural model of different FhbB types was created using the known structure of FhbB $_{35405}$ (pdb code 3R15) (Miller et al., 2011, 2012). Briefly, CLUSTALW2 (Larkin et al., 2007) was used to align the FhbB sequences (residues 24-101). Structural models were generated and compared with the $\mathrm{FhbB}_{35405}$ structure using MODELER9v1 (Sali, 1995;
Sali et al., 1995). Molprobity (version 3.15) (Davis et al., 2004) was used to assess all-atom contacts and geometry. Consurf was used to map the location of conserved and divergent residues using the $\mathrm{FhbB}_{35405}$ as the reference structure (Ashkenazy et al., 2010).

\section{Analyses of the FhbB-FH interaction using affinity ligand-binding immunoblot assays, sucrose octasulfate competitive binding analyses, enzyme-linked immunosorbent assays, and surface plasmon resonance}

$\mathrm{FH}$ affinity ligand-binding immunoblot (ALBI) assays (a membrane overlay approach) were performed as previously described (McDowell et al., 2005). In brief, cell lysates of each strain or recombinant protein were solubilized and separated by sodium dodecyl sulfate-polyacrylamide gel electrophoresis (SDSPAGE). Equal loading of recombinant proteins and protein integrity were assessed by staining with Coomassie blue. Proteins were transferred to polyvinylidene fluoride, overlaid with purified human $\mathrm{FH}$ (10 $\mu \mathrm{g} \mathrm{ml}^{-1}$ in phoshphate-buffered saline with $0.2 \%$ Tween-20 (PBST); Complement Tech, Tyler, TX) and bound $\mathrm{FH}$ was detected using goat anti-FH antiserum (1: 800 dilution, Complement Tech). Horseradish peroxidase-conjugated rabbit anti-goat immunoglobu- 
lin $G$ antibody served as the secondary antibody (1: 20,000 dilution, Calbiochem, San Diego, CA). Treponema denticola strains 35405 and $35405 \mathrm{fhbB}$ served as positive and negative controls for the $\mathrm{FH}$-binding assays, respectively.

Binding of full-length $\mathrm{FH}$ and $\mathrm{CCP}$ constructs to r-FhbB proteins was assessed by enzyme-linked immunosorbent assay (ELISA) as previously described (Miller et al., 2013). Recombinant FhbB proteins were immobilized overnight at $4^{\circ} \mathrm{C}$ in triplicate wells of ELISA plates $(1 \mu \mathrm{g}$ per well in $100 \mathrm{~mm}$ $\mathrm{NaHCO}_{3}, \mathrm{pH}$ 9.6). Borrelia hermsii $\mathrm{FH}$-binding protein, FhbA, and bovine serum albumin were also immobilized and served as positive and negative controls, respectively. Non-specific binding was blocked for $1 \mathrm{~h}$ with $5 \%$ non-fat dry milk in PBST. Purified fulllength human $\mathrm{FH}$ and $\mathrm{r}$-CCP constructs $\left(10 \mu \mathrm{g} \mathrm{ml}^{-1}\right.$ in PBST) were added to the wells for $1 \mathrm{~h}$ followed by three washes with PBST. Goat anti-human $\mathrm{FH}$ (1 : 800 in PBST + 5\% milk; Complement Tech) was added to each well for $1 \mathrm{~h}$, followed by three washes and application of rabbit anti-goat immunoglobulin $\mathrm{G}$ conjugated to horseradish peroxidase $(1: 20,000$ in PBST $+5 \%$ milk) for $1 \mathrm{~h}$. The plates were washed three times with PBST and antibody binding was detected using 2,2'-azino-bis(3-ethylbenzothiazoline6-sulphonic acid; $405 \mathrm{~nm}$ ). The data were normalized to $\mathrm{r}-\mathrm{FhbB}_{35405}$ and averaged across three plates.

To determine whether sucrose octasulfate (SOS) can inhibit $\mathrm{FH}$ binding, plates were coated and nonspecific binding was blocked as described above. $\mathrm{FH}$ $\left(5 \mu \mathrm{g} \mathrm{ml}^{-1}\right)$ was incubated with increasing concentrations of SOS (0-50 mm) in PBST for $1 \mathrm{~h}$ with constant gentle agitation. The immobilized FhbB was overlaid with the $\mathrm{FH}$-SOS solution for $1 \mathrm{~h}$. The wells were washed three times with PBST and binding was detected as described above. The data were normalized to $\mathrm{FH}$ binding with no SOS added. The data presented are representative of three independent experiments.

The kinetics of the FhbB-FH interaction was assessed by surface plasmon resonance using a Biacore T200 and the data were evaluated using BiaEvaluation V1.1 (Biacore, Uppsala, Sweden) (Miller et al., 2012, 2013). Briefly, r-FhbB proteins (ligand) were immobilized on nitrilotriacetic acid chips (GE Healthcare, Chalfont St Giles, UK) via their N-terminal His-tag and increasing concentrations of purified human $\mathrm{FH}$ (analyte; Complement Tech) were added in the fluid phase. The kinetics data were fitted to a Langmuir $1: 1$ binding model and averaged from three replicate experiments.

\section{Measurement of dentilisin activity and $\mathrm{FH}$ cleavage}

The dentilisin activity of each strain was determined by measuring its efficiency in hydrolysis of succinyl-L-alanine-L-alanine-L-prolyl-L-phenylalanine- $p$-nitroanalide (SAAPFNA; Sigma-Aldrich, St Louis, MO) (Uitto et al., 1988; Miller et al., 2013). Aliquots of mid- to late-log phase cultures were pelleted by centrifugation $(5000 \mathrm{~g}, 15 \mathrm{~min}$, $4^{\circ} \mathrm{C}$ ), suspended in buffer $\mathrm{A}\left(100 \mathrm{~mm} \mathrm{NaCl}, 1 \mathrm{~mm} \mathrm{CaCl}_{2}\right.$, $50 \mathrm{~mm}$ Tris- $\mathrm{HCl}, \mathrm{pH}$ 8.0) and transferred to 96-well plates. SAAPFNA ( $1 \mathrm{~mm}$ in buffer $A$ ) was added to each well to a final concentration of $500 \mu \mathrm{m}$ and the absorbance was measured at $405 \mathrm{~nm}$ every $5 \mathrm{~min}$ for $60 \mathrm{~min}$. The data presented are the average of the measurement of three wells per biological replicate and are representative of three replicate experiments. The data are presented as the change in absorbance between the 0-min and 60-min time-points. The dentilisin-mutant strain 35405-CCE (Bian et al., 2005) served as a negative control. Statistical significance was assessed using Student's $t$-test.

Treponema denticola strains were assessed for their ability to degrade $\mathrm{FH}$. In brief, $0.1 \mathrm{OD}_{600}$ of freshly harvested, mid-log phase cells were incubated with $40 \mu \mathrm{g} \mathrm{ml}^{-1}$ human $\mathrm{FH}$ (Complement Tech) in PBS (50- $\mu$ l reaction volume). A sample was immediately removed at $0 \mathrm{~min}$ and the remainder was incubated for $120 \mathrm{~min}$ at $37^{\circ} \mathrm{C}$. The samples were fractionated by SDS-PAGE, transferred to polyvinylidene fluoride and screened with anti-human $\mathrm{FH}$ antiserum (dilution of 1:1000; Complement Tech). Antibody binding was detected using 2,2'-azino-bis(3ethylbenzothiazoline-6-sulfonic acid) at $405 \mathrm{~nm}$.

\section{Serum sensitivity analysis}

Resistance to complement-mediated killing was determined as described in previous studies (McDowell et al., 2011; Miller et al., 2013) with minor modifications. Cells from mid-log phase cultures were incubated with $40 \%$ complement-preserved human serum (NHS; Innovative Research, Novi, MI) in the appropriate growth media (either new oral spirochete medium or OMIZ-P4; $37^{\circ} \mathrm{C}$; anaerobic conditions; 0-3 h). To determine if potential serum-mediated killing was 
complement dependent, strains were also incubated with $40 \%$ serum that had been incubated at $56^{\circ} \mathrm{C}$ for $30 \mathrm{~min}$ to inactivate complement (heat-inactivated serum; HIS). The percentage of intact cells (e.g. \% survival) was determined by cell counts using dark field microscopy (average of 10 fields of view under $1000 \times$ magnification). The values presented represent the number of morphologically intact cells divided by the total number of morphologically intact and disrupted cells (intact cell/intact and disrupted cells $\times 100)$. Cells with multiple outer sheath blebs were determined to be morphologically disrupted.

\section{RESULTS}

\section{Complement resistance of oral treponemes}

A BLAST search of determined oral treponeme genome sequences (Human Microbiome U54 initiative, Broad Institute, Cambridge, MA; broadinstitute.org), revealed that sequences with significant primary sequence homology to $f h b B$ are found only in $T$. denticola. To determine if other oral treponeme species may bind $\mathrm{FH}$ via a protein that is unrelated to $\mathrm{FhbB}$, FH ALBI assays were performed (Fig. 1A). Of the seven species tested, only $T$. denticola 35405 bound human $\mathrm{FH}$ and binding occurred to an 11-kDa protein consistent with the molecular mass of $\mathrm{FhbB}_{35405}$. As expected, $T$. denticola $35405 \delta$ fhbB did not bind $\mathrm{FH}$.

To determine if the inability of some treponemal species to bind $\mathrm{FH}$ correlates with serum sensitivity, representative strains were incubated with $40 \% \mathrm{NHS}$ or HIS and percent survival was determined (Fig. 1B). Less than $5 \%$ of $T$. amylovorum and $T$. vincentii cells survived in the presence of NHS, whereas $>95 \%$ of the cells survived in HIS. Based on these data, it can be concluded that serum-mediated killing of these species is complement-dependent. Treponema medium, T. maltophilum, T. pectinovorum, and T. socranskii were resistant to $40 \%$ NHS with $>90 \%$ survival. These results indicate that five of the seven oral treponemes tested in this study are highly resistant to complement-mediated killing. While $\mathrm{FH}$ binding is essential to the survival of $T$. denticola, it does not contribute to the serum resistance of several other oral treponeme species.

\section{Identification and phylogenetic analysis of fhbB variants}

The fhbB sequences of $T$. denticola isolates 35405 , GM-1 and 33520 were previously determined and found to be nearly identical (McDowell et al., 2007). Recently, a divergent FhbB protein produced by isolate 33521 was identified and demonstrated to bind $\mathrm{FH}$ (Miller et al., 2013). To conduct comprehensive analyses of $f h b B$ phylogenetics, sequences derived from 43 isolates of $T$. denticola were aligned. Four were previously determined, nine were from determined genomes sequences and 30 were determined as part of this study. Phylogenetic analyses delineated three FhbB phyletic clusters that are well
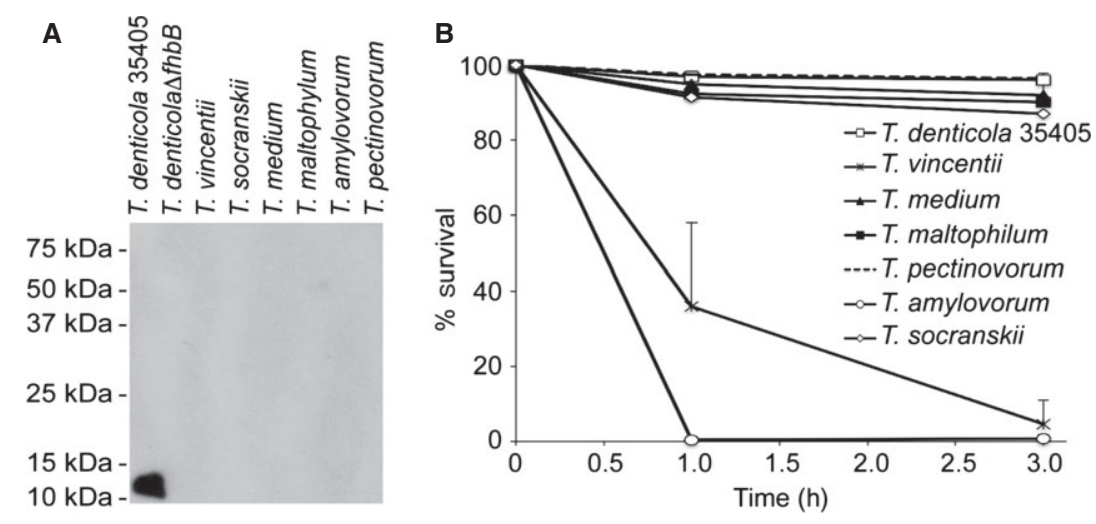

Figure 1 Analysis of factor $\mathrm{H}(\mathrm{FH})$ binding to oral treponemes. (A) Cell lysates of seven oral treponeme species (as indicated above each lane) were solubilized, fractionated by SDS-PAGE, and transferred to membranes. After blocking the membranes were overlaid with purified human $\mathrm{FH}$ and $\mathrm{FH}$ binding detected as detailed in the text using anti-human $\mathrm{FH}$ antibody. To assess serum sensitivity, mid-log phase cultures of each species were incubated in $40 \%$ NHS (B) or HIS (data not shown) for 0,1 or $3 \mathrm{~h}$ under anaerobic conditions. Percent survival, expressed as the number of morphologically intact cells divided by the total number of intact and morphologically disrupted cells $\times 100$, was assessed using dark-field microscropy as detailed in the text. 
supported by bootstrap analysis (Fig. 2). Twenty-one of the sequences (48.8\%) were type 1 FhbB (designated as FhbB1), 14 (32.6\%) were type 2 (FhbB2) and eight (18.6\%) were type 3 (FhbB3). Throughout the manuscript, the isolate of origin for each FhbB sequence, where appropriate to specify, is indicated by subscript (i.e. $\mathrm{FhbB}_{35405}$ ). Sequences within the FhbB1 and FhbB2 clusters are highly conserved at the intra-type level while FhbB3 sequences displayed greater divergence. An alignment of representative sequences is presented in Fig. 2. The structure of FhbB1 $1_{35405}$ was previously determined at $1.7 \AA$

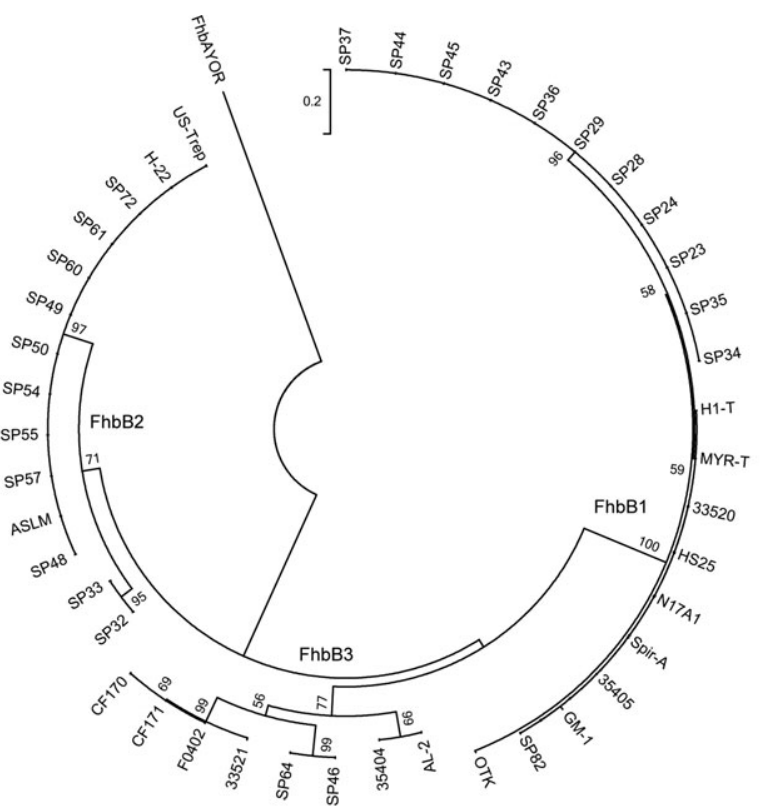

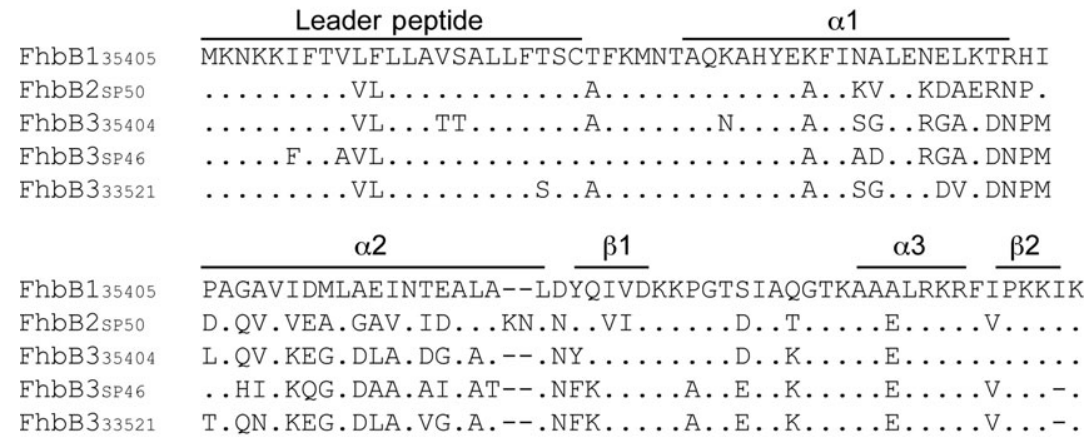

\begin{tabular}{|c|c|c|c|c|c|c|}
\hline & \multicolumn{6}{|c|}{ IDENTITY (\%) } \\
\hline \multirow{6}{*}{ 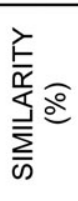 } & & 1 & 2 & 3 & 4 & 5 \\
\hline & $1 \mathrm{FhbB1}_{35405}$ & & 61.7 & 60.8 & 60.8 & 63.3 \\
\hline & $2 \mathrm{FhbB}_{\mathrm{SP} 50}$ & 74.1 & & 64.2 & 66.7 & 70.4 \\
\hline & $3 \mathrm{FhbB}_{\mathrm{SP} 46}$ & 68.4 & 79.0 & & 82.1 & 78.5 \\
\hline & $4 \mathrm{FhbB}_{33521}$ & 73.4 & 76.5 & 85.9 & & 84.8 \\
\hline & $5 \mathrm{FhbB3}_{35404}$ & 70.9 & 79.0 & 87.3 & 88.6 & \\
\hline
\end{tabular}

Figure 2 Identification of three major Treponema denticola FhbB phyletic clusters. The phylogenetic relationships among FhbB sequences $(n=43)$ were assessed using the neighbor-joining method (top panel). The results of bootstrap analyses (500 bootstrap replicates) are indicated at each node. The Borrelia hermsii FhbA $\mathrm{FOR}_{\mathrm{F}} \mathrm{FH}$ binding protein was used to root the tree. The middle panel presents an FhbB amino acid alignment with $\mathrm{FhbB}_{35405}$ serving as the reference strain. Identical residues are shown as dots. Secondary structure elements as inferred from the known atomic structure of FhbB1 35405 (Miller et al., 2011, 2012) are indicated above the alignment. Alpha helices 1-2 map within the negatively charged face of FhbB that has been demonstrated to serve as the $\mathrm{FH}$ interaction domain. The bottom panel presents a matrix of amino acid identity and similarity values (upper and lower quadrants, respectively). 
resolution (Miller et al., 2011, 2012). An amino acid identity/similarity matrix is also presented in Fig. 2. All sequences are predicted to encode lipoproteins with a conserved 23 amino acid leader peptide that, after processing, yields a $\sim 11.4-\mathrm{kDa}$ mature protein that is tethered to the cell surface via its lipid moiety.

To assess potential structural conservation among FhbB variants, representative FhbB1, FhbB2 and FhbB3 sequences were threaded onto the FhbB1 35405 atomic structure. The models obtained were analysed by MolProBITY to identify those with the fewest all-atom clashes and the highest percentage of residues with favored Ramanchandran phi-psi angles. All FhbB variants analysed displayed a high confidence-strong structural fit with the FhbB1 35405 structure. Only minor structural variations were observed (Fig. 3A). Analyses of surface charge distribution maps (overlaid on the structures in Fig. 3) revealed that consistent with FhbB1 $1_{35405}$, all FhbB variants have well defined positively and negatively charged surfaces.
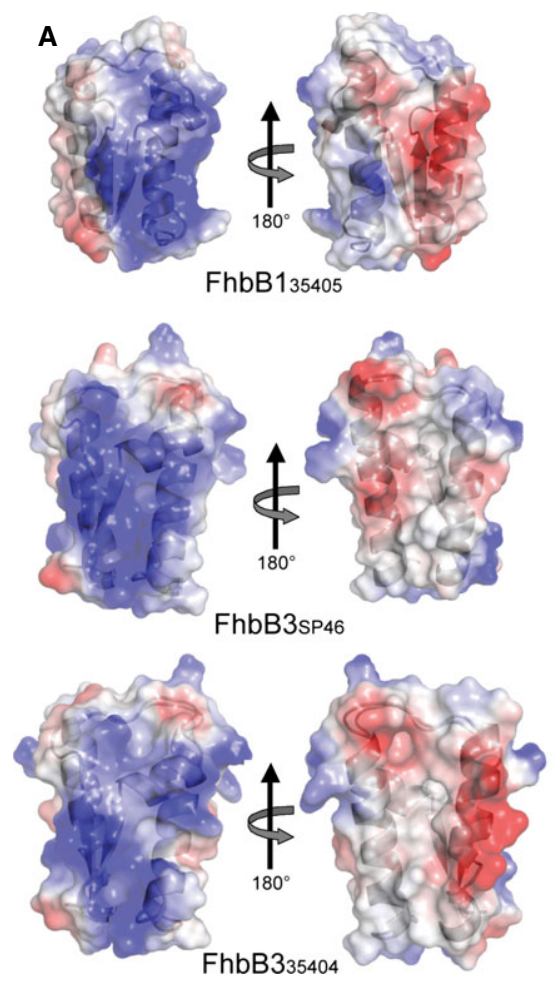

Using all known FhbB amino acid sequences, a sequence conservation map was generated using FhbB1 $1_{35405}$ as the reference structure (Fig. 3B). The greatest degree of sequence diversity among variants maps within residues 20 through 66 (middle of $\alpha$ helix 1 to the C-terminus of ahelix 2). It is this region of FhbB1 that has been demonstrated to serve as the $\mathrm{FH}$ interaction domain (McDowell et al., 2009; Miller et al., 2011, 2013).

\section{Mapping of the FH interaction site for FhbB1, FhbB2 and FhbB3 proteins}

Previous studies demonstrated that the $\mathrm{FH}$-binding site for FhbB1 $1_{35405}$ is within CCP 6-8 and overlaps with a glycosaminoglycan (GAG) -binding site (Giannakis et al., 2003; Miller et al., 2012). In this report, ELISAs were used to investigate the binding of full-length purified human $\mathrm{FH}$ and $\mathrm{r}-\mathrm{FH} \mathrm{CCP}$ constructs to each FhbB type (Fig. 4A). All FhbB proteins bound full-length $\mathrm{FH}$
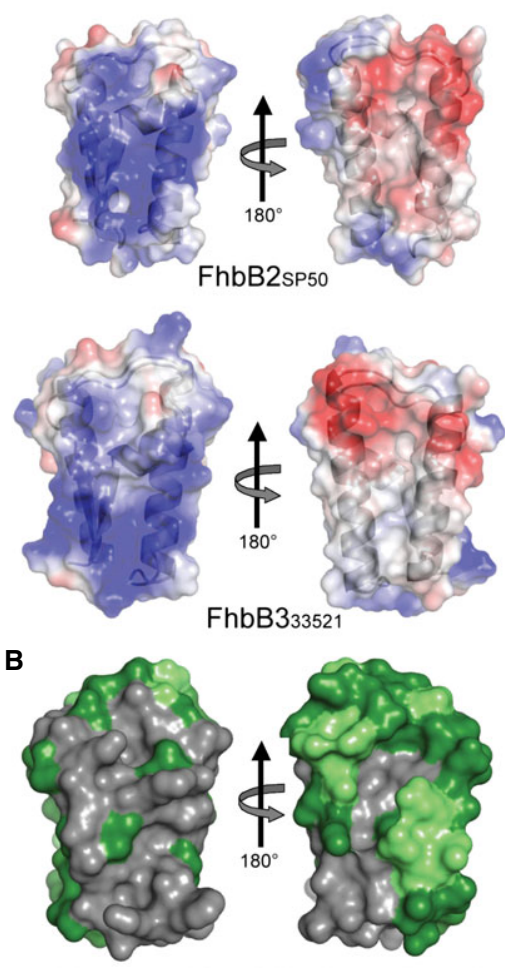

Figure 3 Structural models, charge distribution maps and sequence conservation of FhbB variants. Comparative modeling of the three-dimensional structures of each FhbB type (A) was performed using MoDELLER (University of California San Francisco, San Francisco, CA) based upon the known structure of FhbB1 35405 (PDB 3R15). The ribbon diagrams of FhbB (gray) were overlaid with color-coded, transparent electrostatic surface maps. Residues of negative and positive charge are shown in red and blue, respectively. Each structure was rotated through $180^{\circ}$ to show both the front and back view of each model. (B) A conservation map using the FhbB1 35405 . A conservation score was calculated for each residue using the CoNSURF algorithm. Conserved, variable and highly variable residues shown in gray, light green and dark green, respectively. All methods are described in the text. 

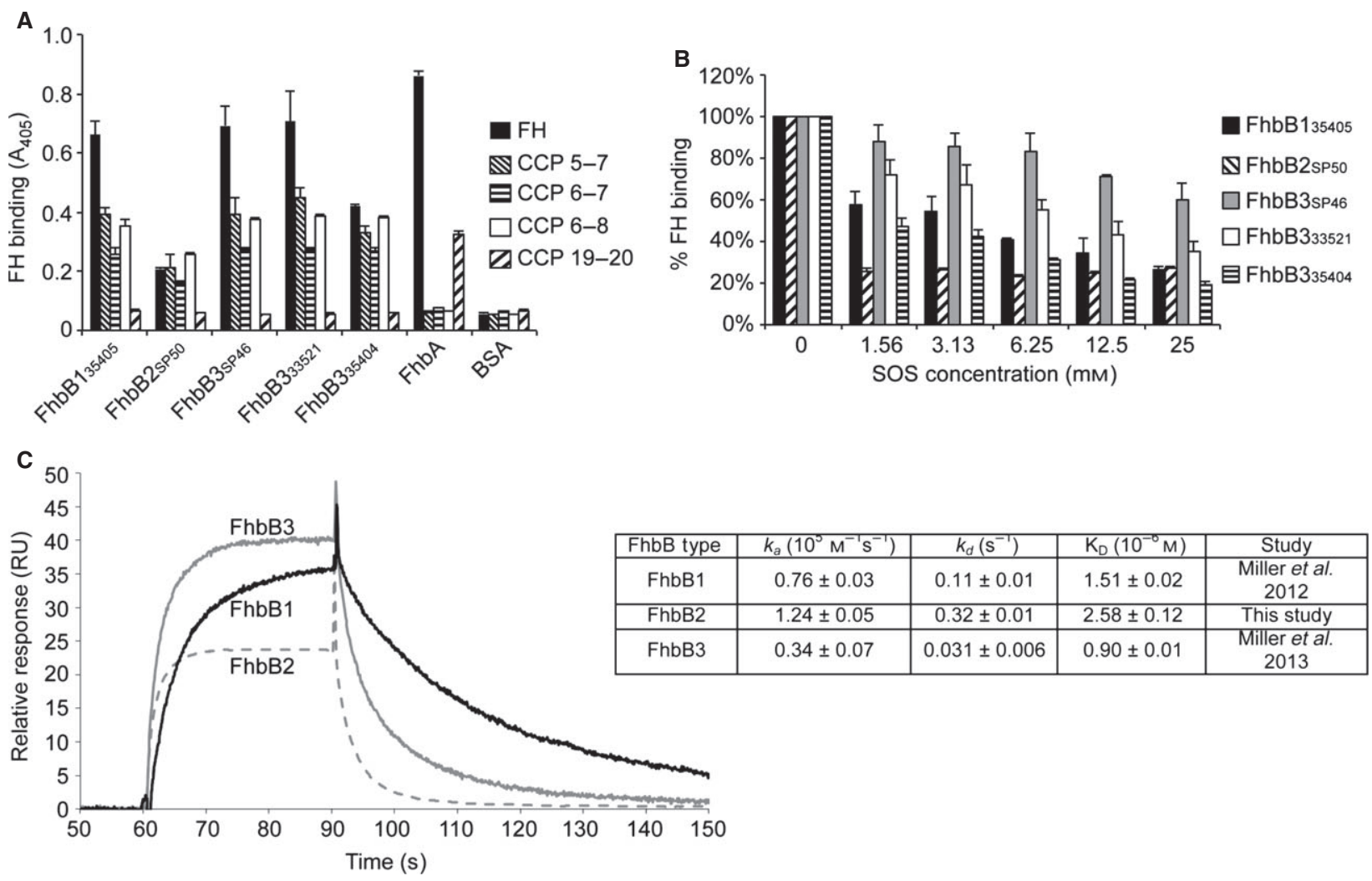

Figure $4 \mathrm{FhbB}$ binding to specific complement control protein (CCP) domains of factor $\mathrm{H}(\mathrm{FH})$ and the influence of the glycosaminoglycan analog, sucrose octasulfate (SOS), on the interaction. ELISA analyses were conducted to localize the binding site(s) of different FhbB variants on FH (A). Recombinant (r-) FhbB variants, r-FhbA (a Borrelia hermsii FH-binding protein) and r-FH subfragments spanning CCP5-7, CCP67, CCP6-8 and CCP19-20 were generated as N-terminal His-tag fusions. The r-FhbB proteins were immobilized in the wells (as indicated) and then full-length $\mathrm{FH}$ or $\mathrm{r}$-CCP constructs were added. Binding was detected using anti-human $\mathrm{FH}$ antiserum, secondary antibody and absorbance. To determine if SOS, which binds to several sites on FH including CCP6-7, inhibits FH binding to different FhbB variants (as indicated above), ELISA analyses were performed (B). ELISA plate wells were coated with each FhbB protein and then FH with increasing concentrations of SOS were added as detailed in the text. After washing, binding was assessed as detailed above. Surface plasmon resonance analyses were conducted to determine if the kinetics of the FH-FhbB interaction differs among FhbB phyletic types (C). The calculated $k_{\mathrm{a}}, k_{\mathrm{d}}$ and $K_{\mathrm{D}}$ values are presented to the right. Note that the data for FhbB1 an FhbB3 were presented in an earlier study.

and $\mathrm{r}-\mathrm{FH}$ constructs consisting of CCP $6-8, \mathrm{CCP}-7$, and CCP 6-7 but not to CCP 19-20. The FH- and plasminogen-binding protein from Borrelia hermsii, FhbA (Hovis et al., 2004; Rossmann et al., 2007), which exclusively interacts with CCP 19-20 of FH (Hovis et al., 2006), served as a binding specificity control. Bovine serum albumin served as a negative control. FhbB2 displayed the lowest level of binding to $\mathrm{FH}$ and the CCP 6-7 domain. To further verify that the FhbB variants bind within the GAG-binding site of $\mathrm{CCP} 6-7$, competitive binding analyses were conducted using SOS, a synthetic GAG-analog (Fig. 4B) (Prosser et al., 2007). SOS inhibited binding of $\mathrm{FH}$ binding to each FhbB type in a dose-dependent manner.

Surface plasmon resonance approaches were employed to compare the binding kinetics of the three major FhbB types with FH (Fig. $4 \mathrm{C}$ ). The $K_{\mathrm{D}}$ value for the FhbB2-FH interaction was similar to that reported for Fhb1 and FhbB3 FH interactions (Miller et al., 2012, 2013). In comparing the kinetics of the interaction of each FhbB type with $\mathrm{FH}$, the $K_{\mathrm{D}}$ value for the FhbB-FH interaction is largely a reflection of a slower off rate. This could compensate for lower affinity binding and allow for more efficient cleavage of $\mathrm{FH}$ by $T$. denticola strains producing FhbB2 proteins.

\section{Serum resistance does not correlate with FhbB type or proteolytic activity}

To determine if dentilisin activity, and thus FH cleavage, correlates with levels of serum resistance, the dentilisin activity of $16 \mathrm{~T}$. denticola strains was 

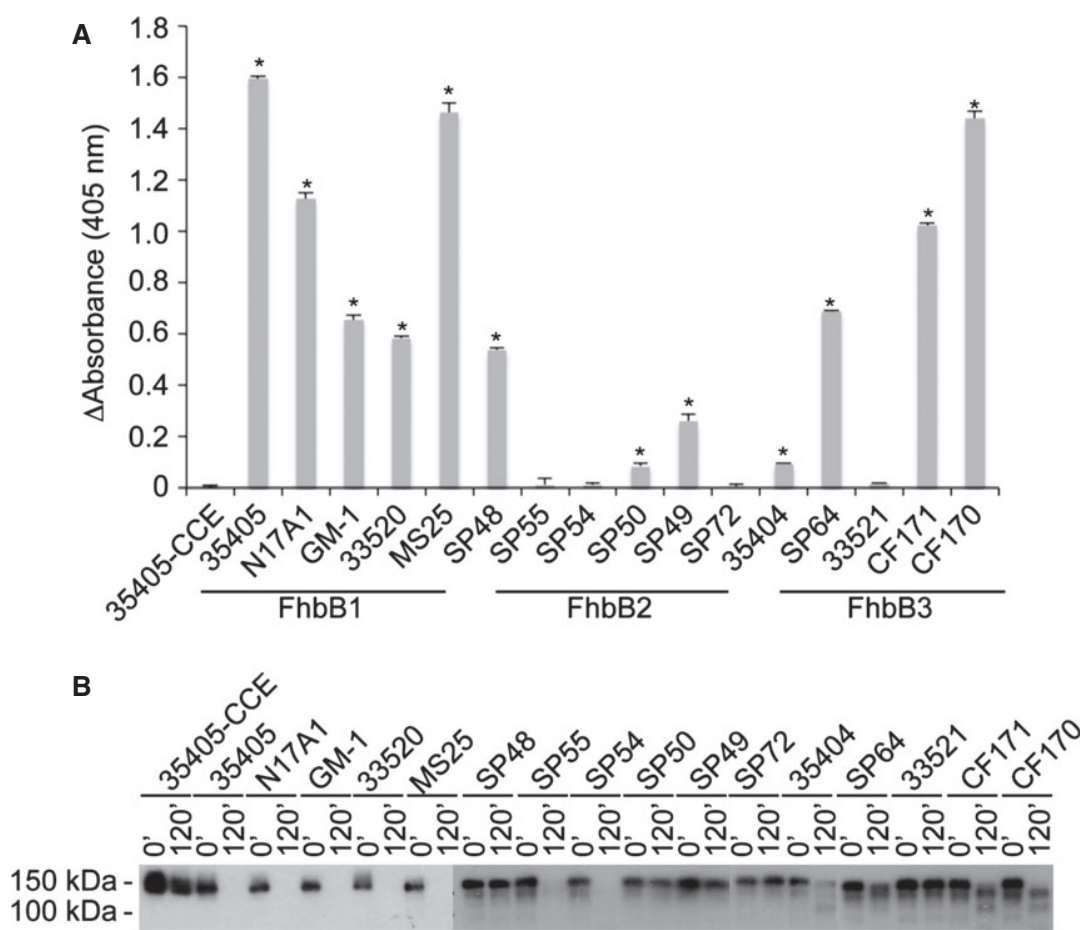

Figure 5 Quantification of the dentilisin activity of Treponema denticola strains producing FhbB1, FhbB2, and FhbB3 proteins. (A) Results of SAAPFNA assays. Mid-log phase cultures were incubated with SAAPFNA and absorbance was read at 0 and 60 min. The absorbance value obtained at $0 \mathrm{~min}$ (background) was subtracted from the value obtained after $1 \mathrm{~h}$ and the average of three assays was plotted. (B) Results of factor $\mathrm{H}(\mathrm{FH})$ cleavage assays are presented. Each strain (as indicated above the panel) was incubated with $\mathrm{FH}$ and aliquots of the supernatant were collected at time 0 and 120 min were fractionated by SDS-PAGE, the proteins were transferred to membranes and the blots were screened with anti-human $\mathrm{FH}$ antiserum as detailed above. The absence of a band at $150 \mathrm{kDa}$ is indicative of $\mathrm{FH}$ cleavage.* $P<0.01$.

determined using the SAAPFNA cleavage assay (Fig. 5A). Dentilisin activity varied widely among strains with some having no discernable activity under the conditions tested. Hence, based on this observation we speculated that strains will differ significantly in their ability to cleave $\mathrm{FH}$. To test this, the

Table 2 Data summary

\begin{tabular}{|c|c|c|c|c|c|}
\hline Isolate & $\begin{array}{l}\text { FhbB } \\
\text { type }\end{array}$ & Dentilisin activity & $\begin{array}{l}\text { Factor H } \\
\text { cleavage }\end{array}$ & $\begin{array}{l}\text { \% Survival } \\
\text { (NHS) }\end{array}$ & $\begin{array}{l}\text { \% Survival } \\
\text { (HIS) }\end{array}$ \\
\hline 35405 & 1 & $1.59 \pm 0.01$ & + & $78.3 \pm 3.6$ & $97.6 \pm 1.5$ \\
\hline MS25 & 1 & $1.46 \pm 0.04$ & + & $92.6 \pm 3.3$ & $98.0 \pm 1.1$ \\
\hline 33520 & 1 & $0.58 \pm 0.01$ & + & $87.5 \pm 3.2$ & $98.9 \pm 0.4$ \\
\hline N17A1 & 1 & $1.13 \pm 0.02$ & + & $92.8 \pm 4.5$ & $99.6 \pm 0.3$ \\
\hline GM-1 & 1 & $0.65 \pm 0.02$ & + & $93.6 \pm 2.3$ & $97.9 \pm 1.3$ \\
\hline SP48 & 2 & $0.54 \pm 0.01$ & + & $94.9 \pm 1.2$ & $96.5 \pm 2.5$ \\
\hline SP55 & 2 & $0.01 \pm 0.02$ & - & $83.4 \pm 20.4$ & $97.2 \pm 0.8$ \\
\hline SP54 & 2 & $0.01 \pm 0.01$ & - & $82.0 \pm 13.2$ & $98.1 \pm 0.8$ \\
\hline SP50 & 2 & $0.08 \pm 0.01$ & - & $86.9 \pm 9.0$ & $95.0 \pm 4.9$ \\
\hline SP49 & 2 & $0.26 \pm 0.02$ & + & $90.0 \pm 14.6$ & $95.4 \pm 4.8$ \\
\hline SP72 & 2 & $0.01 \pm 0.01$ & - & $68.7 \pm 10.2$ & $95.1 \pm 1.4$ \\
\hline 35404 & 3 & $0.09 \pm 0.01$ & + & $88.4 \pm 5.7$ & $98.2 \pm 0.3$ \\
\hline SP64 & 3 & $0.69 \pm 0.01$ & + & $82.6 \pm 3.3$ & $99.0 \pm 0.2$ \\
\hline 33521 & 3 & $0.01 \pm 0.01$ & - & $98.4 \pm 1.7$ & $97.4 \pm 0.2$ \\
\hline CF171 & 3 & $1.02 \pm 0.01$ & + & $93.8 \pm 3.9$ & $97.3 \pm 1.7$ \\
\hline CF170 & 3 & $1.44 \pm 0.03$ & + & $94.5 \pm 3.5$ & $95.7 \pm 1.5$ \\
\hline
\end{tabular}


$\mathrm{FH}$ cleavage ability of each strain was analysed. The majority of strains that produced FhbB2 or FhbB3 proteins either lacked or were attenuated in their ability to cleave $\mathrm{FH}$ (Fig. 5B). This suggests that there may be significant differences in the potential of strains expressing different FhbB types to cause local dysregulation of complement activation.

To determine if production of a given FhbB type protein influences the ability to evade complement-mediated killing, each strain was exposed to $40 \%$ complement-preserved NHS. In this assay, differences in $\mathrm{FH}$ cleavage activity would not be expected to influence serum resistance as the concentration of $\mathrm{FH}$ is high in serum. As a negative control for this assay, cells were also exposed to HIS, which possesses no complement activity. The data are presented in Table 2. All T. denticola isolates were highly resistant to serummediated killing regardless of the FhbB type they produced or dentilisin activity level. The mean percent survival was $89.0 \%$ for FhbB1-producing strains, $84.3 \%$ for FhbB2-producing strains, and $91.5 \%$ for FhbB3-producing strains. These results indicate a trend that mirrors the affinity of each FhbB type for $\mathrm{FH}$. These results suggest that FhbB type does not significantly affect $\mathrm{FH}$ binding or influence serum survival.

\section{DISCUSSION}

The impact of periodontal disease is not confined to the oral cavity as it correlates with increased risk for several systemic diseases (Lopez, 2008; Taylor \& Borgnakke, 2008; Kavoussi et al., 2009; Inaba \& Amano, 2010). Hence, a detailed understanding of phenotypic variation, mechanisms of persistence and serum resistance of oral treponemes is an essential step forward in devising strategies to combat these important pathogens and minimize their impact on overall human health. For oral treponemes to survive and thrive in periodontal pockets they must possess the ability to evade complement-mediated destruction as gingival crevicular fluid possesses levels of complement proteins similar to that of serum. This study is the first comprehensive assessment of the serum sensitivity of oral treponemes associated with periodontal disease and of $T$. denticola phenotypic differences relevant to $\mathrm{FH}$ binding, cleavage and dentilisin activity.

It was previously demonstrated that $T$. denticola strain 35405 evades serum-mediated killing by binding $\mathrm{FH}$ via the FhbB protein (McDowell et al., 2007, 2011). Paradoxically, T. denticola strain 35405 has been demonstrated to cleave $\mathrm{FH}$ that is bound to its surface using the protease, dentilisin (McDowell et al., 2009). Based on this, it was hypothesized that $\mathrm{FH}$ cleavage will result in its local depletion triggering dysregulation of complement activation and the downstream destructive processes that culminate in periodontal disease. To better understand the role of $\mathrm{FH}$ binding in survival of treponemes in the subgingival environment, $\mathrm{FH}$ binding and serum sensitivity of seven oral Treponema species were tested. In addition, we assessed variation in specific phenotypic properties of $T$. denticola that are relevant to immune evasion and the potential to cause immune dysregulation. $\mathrm{FH}$ binding by representative strains of seven oral treponeme species ( $T$. denticola strain 35405, T. socranskii, T. medium, T. pectinovorum, T. maltophilum, T. vincentii and T. amylovorum) was tested using ALBI assays. Among this panel of isolates only T. denticola 35405 bound $\mathrm{FH}$. $\mathrm{FH}$-binding analyses of 15 additional $T$. denticola isolates revealed that this phenotype is shared by 13 of 15 isolates (87\%). While $\mathrm{FH}$ bound only weakly to isolates CF170 and CF171 using the ALBI assay approach, r-FhbB3 proteins derived from these strains bound $\mathrm{FH}$ at a level similar to other r-FhbB proteins and FhbB expression was clearly detected using immunoblot analyses (data not shown). Consistent with the inability of other cultivable treponemal species to bind $\mathrm{FH}$, a homolog of FhbB was not detected in available genome sequences. It can be concluded that among the major cultivable oral treponemes, the $\mathrm{FH}$-binding phenotype is unique to $T$. denticola.

Some pathogens evade complement-mediated killing using non-FH-dependent mechanisms including the binding of complement regulatory proteins C4BP and vitronectin (Potempa et al., 2008; Barbosa et al., 2009; Grosskinsky et al., 2010; Singh et al., 2010; Schwab et al., 2013). To determine if serum-resistant species that do not bind $\mathrm{FH}$ employ non-FH-dependent complement evasion mechanisms, the serum sensitivity of representative isolates of the seven species listed above was assessed. Cells were exposed to $40 \% \mathrm{NHS}$ or $40 \% \mathrm{HIS}$ for $3 \mathrm{~h}$ and cell survival was measured. A serum concentration of $40 \%$ is consistent with the estimated concentration of serum in gingival crevicular fluid (Schenkein \& Genco, 1977a,b). All isolates of $T$. denticola displayed significant serum 
resistance and per cent survival in NHS ranging from 68 to 98\%. Although T. socranskii, T. medium, T. maltophilum and T. pectinovorum do not produce FhbB or bind $\mathrm{FH}$, more than $90 \%$ of the cells survived after $3 \mathrm{~h}$ of exposure to NHS. In contrast, the per cent survival of $T$. vincentii was $40 \%$ after $1 \mathrm{~h}$, dropping to less than $5 \%$ after $3 \mathrm{~h}$. Treponema amylovorum proved to be the most susceptible species with complete killing occurring after $1 \mathrm{~h}$ exposure to NHS. The role of complement in the killing process was confirmed using HIS. No killing was observed with any isolate upon exposure to HIS. The data indicate that T. socranskii, T. medium, T. maltophilum and $T$. pectinovorum employ FhbB- and $\mathrm{FH}$-independent mechanisms to evade complement-mediated killing. To determine if serum-resistant species that do not bind $\mathrm{FH}$, bind $\mathrm{C} 4 \mathrm{BP}$ and or vitronectin, ALBI assays were performed using $20 \%$ human serum as the source for C4BP and vitronectin. Specific binding was not observed (data not shown). Future analyses will focus on identifying the molecular basis of serum resistance for T. socranskii, T. medium, T. maltophilum and T. pectinovorum.

Prior to this study, the impact of $f h b B$ sequence variation on $\mathrm{FH}$ binding had been assessed in only two isolates of T. denticola (35405 and 33521) (Miller et al., 2013). In this study, phylogenetic relationships among $f h b B$ sequences obtained from 43 different $T$. denticola isolates were assessed. Three distinct phyletic clusters were delineated. The proteins encoded by each cluster were designated as FhbB1, FhbB2 and FhbB3. Sequences within the FhbB1 and FhbB2 clusters were found to be highly conserved with a significantly greater degree of variation among FhbB3 sequences. In spite of extensive sequence differences, molecular modelling revealed that all FhbB types possess the negatively charged surface region previously shown to form the $\mathrm{FH}$-binding domain of FhbB1 $_{35405}$ (Miller et al., 2012). However, the highest degree of primary sequence divergence mapped within the $\mathrm{FH}$-binding interface. Recombinant FhbB proteins representing each FhbB type were generated and tested to determine if sequence variation influences binding to $\mathrm{FH}$ or to specific CCP domains. ELISA analyses with the r-FhbB proteins immobilized in the wells revealed similar binding of each protein to full-length $\mathrm{FH}$. All FhbB variants bound to the region of $\mathrm{FH}$ consisting of $\mathrm{CCP}$ domains 6 and 7, but not to an $\mathrm{FH}$ fragment consisting of CCP19-20.
Hence, the $\mathrm{FH}$ interaction domain of diverse $\mathrm{FhbB}$ proteins appears to be similar to that of $\mathrm{FhbB}_{35405}$ (Miller et al., 2012).

CCP6-7 have been demonstrated to be a contact point for several bacterially produced $\mathrm{FH}$-binding proteins (reviewed in Zipfel et al., 2002, 2007; Zipfel \& Skerka, 2009). This region of $\mathrm{FH}$ is also a key interaction site for host-produced GAG (Giannakis et al., 2001, 2003; Prosser et al., 2007). SOS, a GAG analog, binds to multiple sites on FH including CCP7. To further refine the interaction site for FhbB variants on $\mathrm{FH}$, SOS competitive binding analyses were performed. SOS inhibited binding of all variants to $\mathrm{FH}$ or $\mathrm{FH}$-derived fragments, providing further evidence that all FhbB variants use similar contact points with CCP7. Binding kinetics of the $\mathrm{FH}-\mathrm{FhbB}$ interaction were also assessed using surface plasmon resonance. While the $K_{\mathrm{D}}$ values for the $\mathrm{FH}$ interaction with each FhbB type were similar, the on-off rates $\left(k_{\mathrm{a}}\right.$ and $k_{\mathrm{d}}$ ) differed significantly.

Treponema denticola strain 35405 has been demonstrated to cleave $\mathrm{FH}$ in an FhbB-dentilisin-dependent manner (McDowell et al., 2009). To date, comparative analyses of dentilisin activity have been limited to a few strains (Goetting-Minesky et al., 2013) and a potential correlation between dentilisin activity and $\mathrm{FH}$ cleavage in natural isolates has not been assessed. In this study, the dentilisin activity of $16 T$. denticola isolates was measured by monitoring cleavage of the chromogenic substrate, SAAPFNA. Activity varied widely among isolates with some displaying no or minimal activity. This observation is consistent with an earlier study that demonstrated significant differences of dentilisin activity among strains (Goetting-Minesky et al., 2013). Four of the isolates investigated in this study (35405, 33520, 35404 and 33521) were also analysed by Goetting-Minesky et al. (2013). The results obtained in these two studies are in excellent agreement; however, differences in the methods of data analysis resulted in slight differences in conclusions. In this study, we subtracted the absorbance obtained at time zero from the absorbance measured at $2 \mathrm{~h}$ whereas Goetting-Minesky et al. did not. Using this approach we conclude that isolates 35404 and 33521 are devoid of activity as opposed to the conclusion that they possess low-level activity. Dentilisin is considered to be a major virulence factor for T. denticola (Ishihara et al., 1996, 1998; Ellen et al., 2000; Chi et al., 2003; Miyamoto et al., 2006; 
Yamazaki et al., 2006; Bamford et al., 2007; McDowell et al., 2009). Variation in its activity among strains could prove to be of considerable epidemiological value and could influence disease progression. It remains to be determined if strains that display higher levels of dentilisin activity are more virulent. The relative proportion of strains with high vs. low activity within a specific anatomical site could potentially be a contributing factor in disease severity. In analyses of strain 35405 , efficient $\mathrm{FH}$ cleavage was demonstrated to be directly dependent on FhbB and dentilisin (McDowell et al., 2009). The ability of a broad panel of $T$. denticola strains to directly cleave $\mathrm{FH}$, and the dependence of this activity on dentilisin, were assessed. Dentilisin activity was found in all FhbB1 strains tested, whereas FhbB2 and FhbB3 strains did not all yield measurable dentilisin activity. Strains that produce FhbB1 proteins were found to have significantly greater $\mathrm{FH}$ cleavage ability than strains that produce FhbB2 and FhbB3 proteins. However, there were some exceptions as some strains with low dentilisin activity were able to cleave (SP55 and SP54) or partially cleave (35404) FH. It can be concluded that while dentilisin is a key contributor to $\mathrm{FH}$ cleavage, in some strains it is possible that other proteases may also play a role.

In conclusion, this report demonstrates that the serum-resistance phenotype first described for $T$. denticola is shared by several oral treponemes. However, the molecular mechanisms responsible for serum resistance differ among species. Treponema denticola uses an $\mathrm{FH}$-dependent mechanism while other serum-resistant species employ a yet to be defined, $\mathrm{FH}$-independent mechanism. All T. denticola isolates tested, in spite of significant $\mathrm{FhbB}$ sequence variation within their $\mathrm{FH}$ interaction domain, bound $\mathrm{FH}$, but not all strains cleaved $\mathrm{FH}$. The differences in $\mathrm{FH}-\mathrm{FhbB}$ binding kinetics observed for the three FhbB phyletic types and the wide range in dentilisin activity noted among $T$. denticola strains was striking and suggests that in vivo the $T$. denticola population is heterogeneous with regard to these key virulencerelated activities. It is our hypothesis that strains that produce FhbB1 proteins and have higher dentilisin activity will display greater virulence. Hence, the relative proportions of strains present in the subgingival crevice that differ in these activities could significantly influence disease progression and severity. Studies are currently underway to directly address these questions. A human $\mathrm{FH}$ transgenic mouse model that has been extensively used to study the role of $\mathrm{FH}$ binding in the pathogenesis of Neisseria meningitidis (Beernink et al., 2011; Vu et al., 2012) is now being employed by our laboratory to determine if $\mathrm{fhbB}$ genotype, $\mathrm{FH}$ binding, $\mathrm{FH}$ cleavage and dentilisin activity influence alveolar bone loss during periodontal disease.

\section{ACKNOWLEDGEMENTS}

This study was financially supported by grants from NIDCR to R.T.M (DE017401), NIDCR to D.P.M. (DE023000), NIDCR to J.C.F (DE013565) and from $\mathrm{NIH}$ to the VCU Flow Cytometry Core (P30CA160859).

\section{REFERENCES}

Ashkenazy, H., Erez, E., Martz, E., Pupko, T. and BenTal, N. (2010) ConSurf 2010: calculating evolutionary conservation in sequence and structure of proteins and nucleic acids. Nucleic Acids Res 38: W529-W533.

Bamford, C.V., Fenno, J.C., Jenkinson, H.F. and Dymock, D. (2007) The chymotrypsin-like protease complex of Treponema denticola ATCC 35405 mediates fibrinogen adherence and degradation. Infect Immun 75: 4364-4372.

Barbosa, A.S., Abreu, P.A., Vasconcellos, S.A. et al. (2009) Immune evasion of leptospira species by acquisition of human complement regulator C4BP. Infect Immun 77: 1137-1143.

Barthel, D., Schindler, S. and Zipfel, P.F. (2012) Plasminogen is a complement inhibitor. $J$ Biol Chem 287: 18831-18842.

Beernink, P.T., Shaughnessy, J., Braga, E.M. et al. (2011) A meningococcal factor $\mathrm{H}$ binding protein mutant that eliminates factor $\mathrm{H}$ binding enhances protective antibody responses to vaccination. $J$ Immunol 186: 3606-3614.

Bian, X.L., Wang, H.T., Ning, Y., Lee, S.Y. and Fenno, J.C. (2005) Mutagenesis of a novel gene in the prcAprtP protease locus affects expression of Treponema denticola membrane complexes. Infect Immun 73: 1252-1255.

Boackle, R.J. (1991) The interaction of salivary secretions with the human complement system-a model for the study of host defense systems on inflamed mucosal surfaces. Crit Rev Oral Biol Med 2: 355-367.

Boackle, R.J., Pruitt, K.M., Silverman, M.S. and Glymph, J.L. Jr (1978) The effects of human saliva on the hemolytic activity of complement. J Dent Res 57: 103-110. 
Chi, B., Qi, M. and Kuramitsu, H.K. (2003) Role of dentilisin in Treponema denticola epithelial cell layer penetration. Res Microbiol 154: 637-643.

Darveau, R.P. (2010) Periodontitis: a polymicrobial disruption of host homeostasis. Nat Rev Microbiol 8: 481-490.

Davis, I.W., Murray, L.W., Richardson, J.S. and Richardson, D.C. (2004) MOLPROBITY: structure validation and all-atom contact analysis for nucleic acids and their complexes. Nucleic Acids Res 32: W615-W619.

Ellen, R.P. and Galimanas, V.B. (2005) Spirochetes at the forefront of periodontal infections. Periodontology 2000 38: 13-32.

Ellen, R.P., Ko, K.S., Lo, C.M., Grove, D.A. and Ishihara, K. (2000) Insertional inactivation of the prtP gene of Treponema denticola confirms dentilisin's disruption of epithelial junctions. J Mol Microbiol Biotech 2: 581-586.

Ferreira, V.P., Pangburn, M.K. and Cortes, C. (2010) Complement control protein factor $\mathrm{H}$ : the good, the bad, and the inadequate. Mol Immunol 47: 2187-2197.

Giannakis, E., Male, D.A., Ormsby, R.J. et al. (2001) Multiple ligand binding sites on domain seven of human complement factor H. Int Immunopharmacol 1: 433-443.

Giannakis, E., Jokiranta, T.S., Male, D.A. et al. (2003) A common site within factor H SCR 7 responsible for binding heparin, C-reactive protein and streptococcal M protein. Eur J Immunol 33: 962-969.

Goetting-Minesky, M.P., Godovikova, V., Li, J.J. et al. (2013) Conservation and revised annotation of the Treponema denticola prcB-prcA-prtP locus encoding the dentilisin (CTLP) protease complex. Mol Oral Microbiol 28: 181-191.

Grosskinsky, S., Schott, M., Brenner, C., Cutler, S.J., Simon, M.M. and Wallich, R. (2010) Human complement regulators $\mathrm{C} 4 \mathrm{~b}$-binding protein and $\mathrm{C} 1$ esterase inhibitor interact with a novel outer surface protein of Borrelia recurrentis. PLoS Negl Trop Dis 4: e698.

Hovis, K.M., McDowell, J.V., Griffin, L. and Marconi, R.T. (2004) Identification and characterization of a linearplasmid-encoded factor $\mathrm{H}$-binding protein (FhbA) of the relapsing fever spirochete Borrelia hermsii. J Bacteriol 186: 2612-2618.

Hovis, K.M., Jones, J.P., Sadlon, T., Raval, G., Gordon, D.L. and Marconi, R.T. (2006) Molecular analyses of the interaction of Borrelia hermsii FhbA with the complement regulatory proteins factor $\mathrm{H}$ and factor $\mathrm{H}$-like protein 1. Infect Immun 74: 2007-2014.

Hovis, K.M., Freedman, J.C., Zhang, H., Forbes, J.L. and Marconi, R.T. (2008) Identification of an antiparallel coiled-coil/loop domain required for ligand binding by the Borrelia hermsii FhbA protein: additional evidence for the role of FhbA in the host-pathogen interaction. Infect Immun 76: 2113-2122.

Inaba, H. and Amano, A. (2010) Roles of oral bacteria in cardiovascular diseases-from molecular mechanisms to clinical cases: implication of periodontal diseases in development of systemic diseases. J Pharmacol Sci 113: 103-109.

Ishihara, K., Miura, T., Kuramitsu, H.K. and Okuda, K. (1996) Characterization of the Treponema denticola prtP gene encoding a prolyl-phenylalanine-specific protease (dentilisin). Infect Immun 64: 5178-5186.

Ishihara, K., Kuramitsu, H.K., Miura, T. and Okuda, K. (1998) Dentilisin activity affects the organization of the outer sheath of Treponema denticola. J Bacteriol 180: 3837-3844.

Kavoussi, S.K., West, B.T., Taylor, G.W. and Lebovic, D.I. (2009) Periodontal disease and endometriosis: analysis of the National Health and Nutrition Examination Survey. Fertil Steril 91: 335-342.

Larkin, M.A., Blackshields, G., Brown, N.P. et al. (2007) Clustal $W$ and Clustal $X$ version 2.0. Bioinformatics 23: 2947-2948.

Lopez, R. (2008) Periodontal disease and adverse pregnancy outcomes. Evid Based Dent 9: 48.

McDowell, J.V., Lankford, J., Stamm, L., Sadlon, T., Gordon, D.L. and Marconi, R.T. (2005) Demonstration of factor $\mathrm{H}$-like protein 1 binding to Treponema denticola, a pathogen associated with periodontal disease in humans. Infect Immun 73: 7126-7132.

McDowell, J.V., Frederick, J., Stamm, L. and Marconi, R.T. (2007) Identification of the gene encoding the FhbB protein of Treponema denticola, a highly unique factor $\mathrm{H}$-like protein 1 binding protein. Infect Immun $\mathbf{7 5}$ : 1050-1054.

McDowell, J.V., Huang, B., Fenno, J.C. and Marconi, R.T. (2009) Analysis of a unique interaction between the complement regulatory protein factor $\mathrm{H}$ and the periodontal pathogen Treponema denticola. Infect Immun 77: 1417-1425.

McDowell, J.V., Frederick, J., Miller, D.P. et al. (2011) Identification of the primary mechanism of complement evasion by the periodontal pathogen, Treponema denticola. Mol Oral Microbiol 26: 140-149.

Mihlan, M., Stippa, S., Jozsi, M. and Zipfel, P.F. (2009) Monomeric CRP contributes to complement control in fluid phase and on cellular surfaces and increases phagocytosis by recruiting factor $\mathrm{H}$. Cell Death Differ 16: 1630-1640.

Miller, D.P., McDowell, J.V., Bell, J.K. and Marconi, R.T. (2011) Crystallization of the factor H-binding protein, 
FhbB, from the periopathogen Treponema denticola. Acta Crystallogr Sect F Struct Biol Cryst Commun 67: 678-681.

Miller, D.P., Bell, J.K., McDowell, J.V. et al. (2012) Structure of factor $\mathrm{H}$ binding protein $\mathrm{B}(\mathrm{FhbB})$ of the periopathogen, Treponema denticola: insights into the progression of periodontal disease. J Biol Chem 287: 12715-12722.

Miller, D.P., McDowell, J.V., Rhodes, D.V. et al. (2013) Sequence divergence in the Treponema denticola FhbB protein and its impact on factor $\mathrm{H}$ binding. Mol Oral Microbiol 28: 316-330.

Miyamoto, M., Ishihara, K. and Okuda, K. (2006) The Treponema denticola surface protease dentilisin degrades interleukin-1 $\beta$ (IL-1 $\beta$ ), IL-6, and tumor necrosis factor $\alpha$. Infect Immun 74: 2462-2467.

Potempa, M., Potempa, J., Okroj, M. et al. (2008) Binding of complement inhibitor $\mathrm{C} 4 \mathrm{~b}$-binding protein contributes to serum resistance of Porphyromonas gingivalis.

J Immunol 181: 5537-5544.

Prosser, B.E., Johnson, S., Roversi, P. et al. (2007) Structural basis for complement factor $\mathrm{H}$ linked agerelated macular degeneration. J Exp Med 204: $2277-$ 2283.

Ricklin, D., Hajishengallis, G., Yang, K. and Lambris, J.D. (2010) Complement: a key system for immune surveillance and homeostasis. Nat Immunol 11: 785-797.

Rossmann, E., Kraiczy, P., Herzberger, P. et al. (2007) Dual binding specificity of a Borrelia hermsii-associated complement regulator-acquiring surface protein for factor $\mathrm{H}$ and plasminogen discloses a putative virulence factor of relapsing fever spirochetes. J Immunol 178: 7292-7301.

Sali, A. (1995) Comparative protein modeling by satisfaction of spatial restraints. Mol Med Today 1: 270-277.

Sali, A., Potterton, L., Yuan, F., van Vlijmen, H. and Karplus, M. (1995) Evaluation of comparative protein modeling by MODELLER. Proteins 23: 318-326.

Schenkein, H.A. and Genco, R.J. (1977a) Gingival fluid and serum in periodontal diseases. I. Quantitative study of immunoglobulins, complement components, and other plasma proteins. J Periodontol 48: 772-777.

Schenkein, H.A. and Genco, R.J. (1977b) Gingival fluid and serum in periodontal diseases. II. Evidence for cleavage of complement components $\mathrm{C} 3, \mathrm{C} 3$ proactivator (factor B) and C4 in gingival fluid. $J$ Periodontol 48: 778-784.

Schwab, J., Hammerschmidt, C., Richter, D. et al. (2013) Borrelia valaisiana resist complement-mediated killing independently of the recruitment of immune regulators and inactivation of complement components. PLoS One 8: e53659.

Sievers, F., Wilm, A., Dineen, D. et al. (2011) Fast, scalable generation of high-quality protein multiple sequence alignments using Clustal Omega. Mol Syst Biol 7: 539.

Singh, B., Su, Y.C. and Riesbeck, K. (2010) Vitronectin in bacterial pathogenesis: a host protein used in complement escape and cellular invasion. Mol Microbiol 78: 545-560.

Socransky, S., Haffajee, A., Cugini, M., Smith, C. and Kent, R.J. (1998) Microbial complexes in subgingival plaque. J Clin Periodontol 25: 134-144.

Tamura, K., Peterson, D., Peterson, N., Stecher, G., Nei, M. and Kumar, S. (2011) MEGA5: molecular evolutionary genetics analysis using maximum likelihood, evolutionary distance, and maximum parsimony methods. Mol Biol Evol 28: 2731-2739.

Taylor, G.W. and Borgnakke, W.S. (2008) Periodontal disease: associations with diabetes, glycemic control and complications. Oral Dis 14: 191-203.

Uitto, V.J., Grenier, D., Chan, E.C. and McBride, B.C. (1988) Isolation of a chymotrypsinlike enzyme from Treponema denticola. Infect Immun 56: 2717-2722.

Vu, D.M., Shaughnessy, J., Lewis, L.A., Ram, S., Rice, P.A. and Granoff, D.M. (2012) Enhanced bacteremia in human factor $\mathrm{H}$ transgenic rats infected by Neisseria meningitidis. Infect Immun 80: 643-650.

Yamazaki, T., Miyamoto, M., Yamada, S., Okuda, K. and Ishihara, K. (2006) Surface protease of Treponema denticola hydrolyzes C3 and influences function of polymorphonuclear leukocytes. Microbes Infect 8: 1758-1763.

Zipfel, P.F. and Skerka, C. (2009) Complement regulators and inhibitory proteins. Nat Rev Immunol 9: 729-740.

Zipfel, P.F., Skerka, C., Hellwage, J. et al. (2002) Factor $\mathrm{H}$ family proteins: on complement, microbes and human diseases. Biochem Soc Trans 30: 971-978.

Zipfel, P.F., Wurzner, R. and Skerka, C. (2007) Complement evasion of pathogens: common strategies are shared by diverse organisms. Mol Immunol 44: 3850-3857. 